\title{
The possible role of cytomegalovirus infection and pro-inflammatory I L_ 2 cytokine in preeclampsia
}

Background and Objective: Fragmentary evidence suggests that trophoblast viral infection may play a role in placental dysfunction leading to complications like Preeclampsia. Among these, placental exposure to CMV induces an inflammatory response that precedes invasive trophoblast cell death. This study aimed to assess the frequency of anti-CMV IgG seropositivity and IL2 level in serum in patients with preeclampsia compared to normotensive control pregnant women.

Methods: A total of 90 women were enrolled, of which 60 had preeclampsia and 30 normotensive pregnant women as the control. A serum sample was collected from each subject and was investigated for anti-CMV IgG serostatus and IL-2 concentration using Enzyme-Linked Immunosorbent Assay (ELISA) based kits.

Results: In preeclamptic and normotensive pregnant women, $33.3 \%$ and $16.6 \%$ of the tested sera were seropositive for anti CMV IgG antibodies respectively $(P=0.136)$. Early onset preeclamptic women revealed a high frequency of anti-CMV seropositivity $(80 \%)$ when compared with late onset Preeclampsia (20\%). Cytokine assessment revealed a higher IL-2 level in preeclamptic women seropositive for anti-CMV IgG although statistically was not significant $(P=0.14)$, but in normotensive women, the IL-2 level was significantly higher in sera seropositive for anti-CMV $\lg G(P=0.02)$.

Conclusion: This study delineates a high frequency of anti-CMV IgG antibodies particularly those with early onset preeclampsia; with no significant difference for the IL-2 level.

Keywords: Preeclampsia; CMV; IL-2 cytokine.

\section{Introduction}

The origin of preeclampsia, a hypertensive disorder unique to pregnancy is still a matter of debate and numerous theories have suggested. The pathophysiology of the disease involves impaired trophoblast invasive, abnormal genetic polymorphism, vascular endothelial cell activation, immune tolerance by the maternal immune system and an exaggeration of a systematic inflammatory process. $^{1}$ Perturbation of the immune system is a central feature in the maternal generalized inflammatory response of preeclampsia; ${ }^{2}$ among player microbial factors like Chlamydia pneumonia, ${ }^{3}$ Chlamydia trachomatis, ${ }^{4}$ Helicobacter pylori, ${ }^{5}$ Human papillomavirus, ${ }^{6}$ and cytokines like TNF- $\alpha,{ }^{7}$ $\mathrm{IL}-1,{ }^{8} \mathrm{IL}-6,{ }^{9} \mathrm{IL}-12,{ }^{10} \mathrm{IL}-18,{ }^{11}$ and INF-Y ${ }^{12}$ are thought to be involved in the pathogenesis of preeclampsia for a long time. ${ }^{13,14}$ Data strongly focused on the alteration of the equilibration between $\mathrm{TH} 1$ and $\mathrm{TH} 2$ lymphocytes in preeclamptic trophoblast, ${ }^{15}$ in favor of an increase of TH1 profile with the consequence of defect in the expression of IL-2. ${ }^{16,17}$ During steady-state conditions IL-2 produced by CD $4^{+} \mathrm{T}$ helper cell in secondary lymphoid organs and to lesser extent, by $\mathrm{CD}^{+} \mathrm{T}$ cell, Natural killer cell $(\mathrm{NK}){ }^{18}$ can be synthesized in small amount by activated Dendritic cell (DC)

* Rizgary Teaching Hospital, Ministry of Health, Erbil, I raq.

** Department of Microbiology, College of Medicine, Hawler Medical University, Erbil, I raq.

*** Department of Microbiology, College of Education, Salahaddin University, Erbil, I raq. 
and mast cell. $^{19}$ Interleukin-2 (IL-2) is a pleiotropic cytokine produced after antigen activation that plays pivotal roles in the immune response. Discovered as a $T$ cell growth factor, IL-2 additionally promotes $\mathrm{CD}^{+} \mathrm{T}$ cell and natural killer cell cytolytic activity and modulates $T$ cell differentiation programs in response to antigen, promoting native $\mathrm{CD}^{+} \mathrm{T}$ cell differentiation into $T$ helper 1 (Th1) and $T$ helper 2 (Th2) cells while inhibiting T helper 17 (Th17) and T follicular helper (Tfh) cell differentiation. Moreover, IL-2 is essential for the development and maintenance of $T$ regulatory cells and activation-induced cell death, thereby mediating tolerance and limiting inappropriate immune reactions. ${ }^{20}$ IL-2, TNF- $\alpha$, and IFN- $\gamma$ are characteristic of $\mathrm{T}$ helper 1 (Th1)-type immunity, induce several cell-mediated cytotoxic and inflammatory reactions. ${ }^{21}$ The association between CMV placental infection and adverse obstetric outcomes revealed that CMV can inhibit placental cytotrophoblast cell invasion through extracellular matrices; that consequently associated with placental dysfunction. ${ }^{22-24} \mathrm{CMV}$ can also damage trophoblast cell via induction of TNF- $\alpha$ and the consequences of adverse obstetric outcomes. $^{25}$ There are several potential mechanisms by which CMV infection might contribute to the pathogenesis of preeclampsia. It has been reported that preeclampsia is associated with Toll-like receptor (TLR') up-regulation, CMV infection can activate inflammatory cytokines response via $\mathrm{CD}^{+} 4$ and Toll-like receptor 2 . This binding may contribute to the stimulation of immune pro-inflammatory cytokines observed in preeclampsia. Second, CMV can augment the expression of macrophage-colony stimulate factor and result in pro-coagulant activation through altering the coagulate balance of endothelial, all of which could trigger the maternal syndrome of preeclampsia. Third, CMV infection, as well as other infectious agents may be involved in lowering the threshold level at which the clinical phenotype of preeclampsia is triggered. ${ }^{26}$
Therefore, this study aimed to compare the frequency of seropositivity of anti-CMV IgG and IL-2 levels between preeclamptic and normotensive control pregnant women and to determine whether the level of IL-2 correlated with anti-CMV IgG seropositivity in both groups.

\section{Methods}

This study is a case-control prospective approach conducted at Maternity and Obstetrics hospital in Erbil city, Kurdistan, Iraq. The women enrolled were 60 preeclamptic and 30 normotensive control pregnant women. This number of controls seems to be statistically representative to the size of test samples. Though it is the minimum quantity that can be taken as control. Nevertheless, this study was intended to undertake test samples rather than controls considering all the limitations during sample collection and challenges in performing the experiments. The preeclamptic cases were at gestational age 26-39 weeks. The preeclamptic women were further classified as early onset preeclampsia ( $<34$ weeks gestation) and late onset preeclampsia (>34 weeks gestation). Preeclampsia was diagnosed according to the criteria recommended by the American college of obstetrician and gynecologists in 2002. ${ }^{27}$ Thus systolic blood pressure of $140 \mathrm{mmHg}$ or higher and diastolic blood pressure of $90 \mathrm{mmHg}$ or higher on two occasions occurring after 20 weeks gestation in pregnant women with previous history of normotensive blood pressure and detectable protein in the urine $(\geq 1+1$ by dipstick or $\geq 0.3 \mathrm{~g} / 24 \mathrm{hrs}$ ) were diagnosed as preeclampsia cases. Bloodnsamples were collected from both groups and the sera were separated and stored at $-40^{\circ} \mathrm{C}$ until performance of the ELISA assay; the procedure as written in the leaflet of kit was: Prepare 1:40 dilutions by adding $5 \mu$ of the test samples, negative control, positive control, and calibrators to $200 \mu \mathrm{l}$ of sample diluents. Mix well; dispense $100 \mu \mathrm{l}$ of diluted sera, calibrator, and controls into the appropriate 
wells. For the reagent blank, dispense 100 $\mu$ sample diluents in $1 \mathrm{~A}$ well position. Tap the holder to remove air bubbles from the liquid and mix well. Incubate for 30 minutes at room temperature, Remove liquid from all wells. Repeat washing three times with washing buffer. Dispense $100 \mu$ l of enzyme conjugate to each well and incubate for 30 minutes at room temperature; Remove enzyme conjugate from all wells. Repeat washing three times with washing buffer; dispense $100 \mu \mathrm{l}$ of $(3,3,5,5$-tetramethylbenzidine) TMB Chromogenic Substrate to each well and incubate for 15 minutes at room temperature. Add $100 \mu \mathrm{l}$ of Stop Solution to stop the reaction, make sure there are no air bubbles in each well before reading, Read optical density at $450 \mathrm{~nm}$ immediately for detectable of anti-CMV IgG antibody and estimation of the concentration of IL-2 cytokine in both groups. Serum IL-2 level was measured with ELISA kit using Human Interleukin (IL-2) provided by (BioVision - USA, Cat: K4798-100) according to manufacturer instruction. The standard range: $82-102 \%$ and Sensitivity: 94.6\%). Also, Anti-CMV IgG was assessed by ELISA Kit (AccuDiag $^{\text {TM }}$ - USA, Cat: 1201-11 Sensitivity: $97.0 \%$ and Range: $64-92 \%$ ).

\section{Ethical consideration:}

The study proposal was approved by the Research Ethics Committee of the College of Health Sciences, Hawler Medical University.

Statistical analysis:

The statistical package for the social sciences (version 21.0) was used to attain the descriptive and inferential analysis of data. Thus, the results of the studied groups were analyzed statistically using the student t-test for numeric data, Chi-square test for non-parametric data, and Spearman correlation to determine the collective effect of parameters. The association between groups was assigned as statistically significant at $P$ value less than 0.05 .

\section{Results}

Table 1 shows that there was no statistically significant difference in frequency of anti-CMV IgG seropositivity $(33.3 \%)$ in sera of preeclamptic patients, when compared with its frequency $(16.6 \%)$ in sera of normotensive control pregnant women $(P>0.05)$. According to the onset of disease, $80 \%$ the seropositive cases were confined to early onset disease and $20 \%$ among late onset preeclampsia (Table 2).

Table 1: Seroprevalence of anti-CMV IgG in preeclamptic and normotensive pregnant women.

\begin{tabular}{llcccc}
\hline Test & & $\begin{array}{c}\text { Cases } \\
\text { No.\% }\end{array}$ & $\begin{array}{c}\text { Control } \\
\text { No.\% }\end{array}$ & $\begin{array}{c}\text { Total } \\
\text { No.\% }\end{array}$ & P value \\
\hline Anti-CMV IgG & Positive & $20(33.3 \%)$ & $5(16.6 \%)$ & $25(27.8 \%)$ & 0.136 \\
& Negative & $40(66.6 \%)$ & $25(83.4 \%)$ & $65(72.2 \%)$ & \\
\multirow{2}{*}{ Total } & & $60(100 \%)$ & $30(100 \%)$ & $95(100 \%)$ & \\
\hline
\end{tabular}

Table 2: Distribution of anti-CMV $\lg$ seropositivity according to the onset of preeclampsia .

\begin{tabular}{llcc}
\hline \multirow{2}{*}{ Test } & & Early onset preeclampsia & Late onset preeclampsia \\
& & No.\% & No.\% \\
\hline \multirow{2}{*}{ Anti-CMV IgG } & Positive & $16(88 \%)$ & $4(20 \%)$ \\
& Negative & $4(20 \%)$ & $16(80 \%)$ \\
\hline
\end{tabular}


(Tables 3) clarify the mean concentration of IL-2 cytokine in preeclamptic women seropositive and negative for anti-CMV

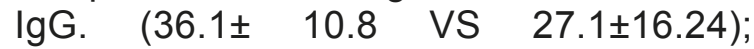
statistically no significant differences was seen $(P=0.14)$. But in normotensive pregnant women, a significant difference was observed between anti-CMV IgG seropositive and negative. (15.1 \pm 10.7 VS $1.71 \pm 2.4) P=0.02$. Figure 1 and 2 delineates the correlation between IL-2 concentration and anti-CMV IgG level in both preeclamptic and normotensive pregnant women; both might have a causal factor in the pathophysiology of the preeclampsia. The correlation coefficient value of the tested parameters namely anti-CMV IgG and IL-2 concentration in preeclampic cases were $(r=0.43)$, $(P=0.14)$ which refer to positive correlation, meanwhile was negative in normotensive women $(r=0.39),(P=0.02)$ as shown in Figure 1 and 2, respectively.

Table 3: Mean IL-2 serum concentration among Preeclamptic and normotensive Seropositive and negative for anti-CMV IgG.

\begin{tabular}{lcccccc}
\hline $\begin{array}{l}\text { Studied } \\
\text { group }\end{array}$ & No. & $\begin{array}{c}\text { Concentration } \\
\text { of IL-2 (pg/ml) } \\
\text { (Mean } \pm \text { SD) }\end{array}$ & $\begin{array}{c}\text { CMV serostatus } \\
\text { Seropositive } \\
\text { in CMV IgG }\end{array}$ & $\begin{array}{c}\text { Seronegative } \\
\text { in CMV IgG }\end{array}$ & t. value & $\boldsymbol{P}$ value \\
\hline $\begin{array}{l}\text { Preeclamptic } \\
\text { women }\end{array}$ & 60 & IL-2 (Mean $\pm S D)$ & $36.1 \pm 10.8$ & $27.1 \pm 16.24$ & 0.14 & $>0.05$ \\
$\begin{array}{l}\text { Normotensive } \\
\text { pregnant } \\
\text { women }\end{array}$ & 30 & IL-2 (Mean $\pm S D)$ & $15.1 \pm 10.7$ & $1.17 \pm 2.4$ & 0.02 & $<0.05^{*}$ \\
\hline
\end{tabular}

IL-2: interleukine-2; SD Standard Deviation;

*paired sample t-test; $p<0.05$ statistically significant.

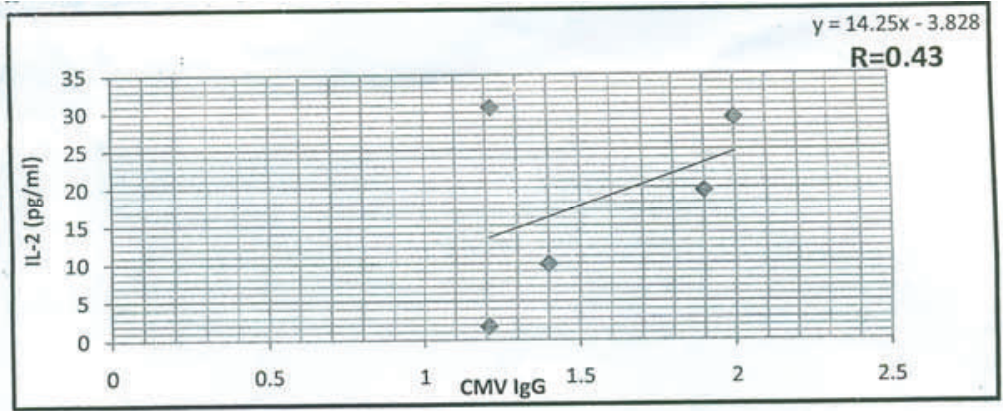

Figure 1: Correlation between IL2 level and anti-CMV IgG in preeeclamptic women. r- Spearman rank correlation Coefficient.

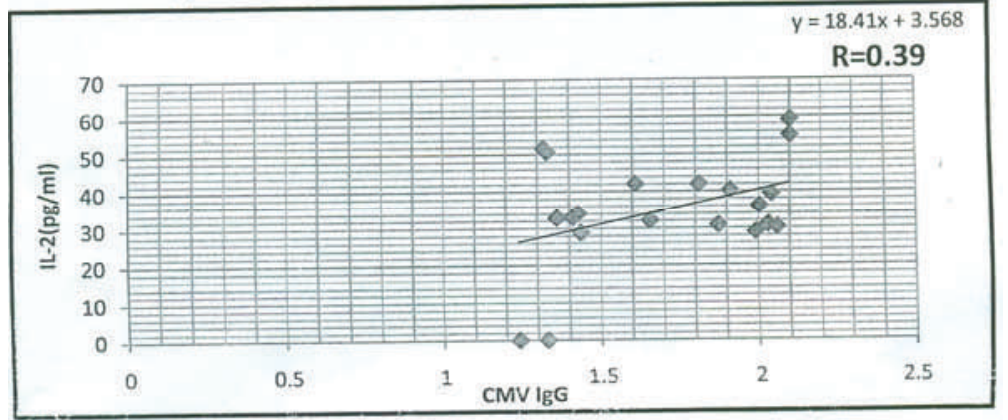

Figure 2: Correlation between IL-2 level and anti-CMV IgG in normotensive women. r- Spearman rank correlation Coefficient. 


\section{Discussion}

Preeclampsia is a common disease in pregnant women and a leading cause of entire vascular endothelial cell dysfunction. ${ }^{28}$ Epidemiologic studies have shown that maternal infection and preeclampsia are connected and the link could be via Toll-like Receptor activation. ${ }^{29-}$ ${ }^{31}$ In early pregnancy, CMV infection can cause fetal death and miscarriage, ${ }^{32}$ adversely affect placentation with subsequent pregnancy complication such as preeclampsia. ${ }^{33}$ The data from the present study showed that seropositivity for anti-CMV IgG was higher in preeclamptic patients as compared to normotensive control pregnant women, but statistically non-significant $(P>0.05)$. Regarding the relation between anti-CMV IgG seroprevalence and the onset of disease, the seroprevalence was higher among the patients with early onset preeclampsia cases. Association between CMV antibodies in pregnancy and development of preeclampsia is inconsistent. ${ }^{34-36}$ It has been confirmed the elevated CMV antibodies level ${ }^{35}$ and genomic DNA load in women with early onset preeclampsia was reported or confirmed. ${ }^{37,38}$ However, Strand et $\mathrm{al}^{39}$ reported lower anti CMV IgG seropositivity in preeclamptic women than healthy. The risk for developing preeclampsia was confirmed by others to be associated with increased prevalence of CMV IgG together with increased CMV IgG antibodies level. ${ }^{34,35}$ This may be explained by the fact that the increased risk for developing preeclampsia in women with specific HLA-G alleles may be combined with CMV infection. ${ }^{4}$ It has been stated that CMV infection impairs trophoblast differentiation and invasion. This leads in turn to down-regulate matrix metalloproteinase (MMP) activity in uterine micro vascular endothelial cells and differentiating invading cytotrophoblast. ${ }^{25}$ In addition to reduced MMP activity early in placental development could impair cytotrophoblast. Remodeling of the uterine vessels and eventually restrict fetal growth in affected pregnancy. ${ }^{25}$ Also, Fisher et al. ${ }^{41}$ demonstrated that endothelial cells are targets of infection by CMV. Thus, remodeling of uterine spiral arterioles suggests that CMV can spread from maternal vascular to endovascular cytotrophoblast in the uterus. Our results agree with other who reported that women with early-onset PE ( $<34$ weeks) have higher IgG HCMV titers than women with late-onset. ${ }^{35}$ Moreover, in the placenta, the increased cytokine production especially $\mathrm{TH} 1$ profile may be an important component of the immune inflammatory response that impairs trophoblast invasion and results in trophoblast death. ${ }^{42}$ The impact, are associated with adverse outcomes that include fetal growth restriction preeclampsia and spontaneous preterm delivery. Of those TH1 cytokine IL-2 plays a key role in regulating the balance between immunity and tolerance. ${ }^{35,43,44}$ In this study, preeclamptic women seropositive for CMV-lgG, the IL-2 concentration was elevated but statistically not significant in comparison with seronegative CMV-IgG level $(P>0.05)$. Results obtained in this study indicated that the mean concentration of IL-2 was significantly higher in normotensive women seropositive for CMV-lgG as compared to seronegative group $(P<0.05)$. Of interest in this study finding a positive correlation between IL-2 and CMV-IgG seropositivity in preeclamptic women. A study done by Gallersen et al. ${ }^{28}$ demonstrated that during pregnancy, HLA-G is expressed on trophoblastic cells at the maternal fetal interface and may be involved in the local immune response to viral infection. The reduced HLA-G expression is a feature of the preeclamptic placenta. $^{28}$ In this regard, CMV-infected cytotrophoblast down-regulate HLA-G which may play a role in maternal immune tolerance ${ }^{41}$ and consequently alter the critical maternofetal immune interface leading to preeclampsia. $^{28}$ The possible role of IL-2 elevation in the pathophysiology of $\mathrm{PE}$ especially during the first trimester of 
pregnancy may be linked to the IL-2 reduced angiogenesis in placenta. ${ }^{45,46}$ In addition, IL-2 elevation in PE can lead to IL -2 induced proliferation and natural killer activation. ${ }^{46,47}$ Consequently, NK-cell of decidual origin acquired a broad cytolytic potential in response to IL-2 cytokine that may have a role in the control of unduly invasive trophoblast. ${ }^{47}$

\section{Conclusion}

This study concluded that a high frequency of IgG anti-CMV in preeclamptic women especially in early onset $\mathrm{PE}$ that reflects the important role of CMV in the pathoaetiology of preeclampsia. IL-2 as TH1 marker in preeclamptic women seropositive for IgG anti-CMV revealed a non-significant elevation with surprisingly a positive moderate correlation. In future, this study needs to be extended to evaluate the role of other cytokines and microbial factors like IFN- $\gamma$, TNF- $\alpha$, Helicobacter pylori and Chlamydia pneumonia.

\section{Competing interests}

The authors declare that they have no competing interests.

\section{References}

1. Schiessl B. Inflammatory response in preeclampsia. Mol Aspects Med 2007; 28:210-9.

2. Luppi $P$, Deloia JA. Monocytes of preeclamptic women spontaneously synthesize pro-inflammatory cytokines. Clin Immunology 2006; 118(2-3):268-5.

3. Xie F, Hu Y, Magee LA, Money DM, Patrick DM, Brunham RM, et al. Chlamydia pneumonia infection in preeclampsia. Hypertens Pregnancy 2010; 29:468-7.

4. Haggerty $C L$, Mark $A K$, Inge $P$, Soren $A U$, Debra CB, Jorn O. Prenatal Chlamydia trachomatis infection increase the risk of Preeclampsia. Hypertens Pregnancy 2013; 3: 151-1.

5. Tersigni C, Francesco F, Tullia T, Simona C, Giovanni S, Nicoletta DS. Insights into the Role of Helicobacter pylori infection in Preeclampsia: From the Bench to the Bedside. Front Immunol 2014; 5:484.

6. McDonnold M, Holly D, Ashley H, Luis DP, Gary DV, George RS, et al. High risk human papillomavirus at entry to prenatal care and risk of preeclampsia. Am J Obstet Gynecol 2014; 210:138-5.
7. Benyo DF, Smarason A, Redman CW, Sims C, Conrad KP. Expression of inflammatory cytokines in placentas from women with preeclampsia. J Clin Endocrinol Metab 2001; 86:2505-2.

8. Conrad JP, Benyo DF. Placental cytokines and the pathogenesis of preeclampsia. Am J Reprod Immunol 1997; 37:240-2.

9. Huang $X$, Hefeng $H$, Minyue $D$, Qiwei $Y$, Hanshi W. Serum and placental interleukin-18 are elevated in preeclampsia. J Reprod Immunol 2005; 65:77-8.

10. Sakai M, Hiroshi T, Kyoko T, Yasushi S, Shigeru $\mathrm{S}$. Interleukin 12 secretions by peripheral blood mononuclear cells is decreased in normal pregnant subjects and increased in preeclamptic patients. Am J Reprod Immunol 2002; 47:91-9.

11. Lockwood CJ, Yen CF, Basar M, Kayisli UA, Martel M, Buhimschi I, et al. Preeclampsia related inflammatory cytokines regulate interkeukin-6 expression in human decidual cells. Am J Pathol 2008; 172:1571-9.

12. Wilczinski JR, Tchorzeski $H$, Banasik $M$. Lymphocyte subset distribution and cytokine secretion in third trimester decidua in normal pregnancy and preeclampsia. Eur $\mathrm{J}$ Obstet Gynecol Reprod Biol 2003; 109:8-1.

13. Kup Fermin MJ, Peaceman AM, Wigton TR, Tamura RK, Rehnbery KA, Socol ML. Immunoreactive tumor necrosis factor alpha is elevated in maternal plasma but undetected in amniotic fluid in the second trimester. Am J Obstet Gynecol 1994; 171(4):975-9.

14. Conrad KP, Miles TM, Benyo DF. Circulating level of immunoreactive cytokines in women with preeclampsia. Am J Repord Immunol 1998; 40 (2):102-1.

15. Hill JA, Choi BC. Maternal immunological aspects of pregnancy success and failure. J Repord Fertili Suppl 2000; 55:91-7.

16. Doris C, Yujie M, Jian Z, Cindy M, Samuel P. Cytomegalovirus infection of trophoblast cells elicits an inflammatory response: A possible mechanism of placental dysfunction. Am J Obstet Gynecol 2006; 194:535-4.

17. Saito S, Sakai M, Sasaki Y, Tanebe K, Tsuda H, Michimata T. Quantitative analysis of peripheral blood $\mathrm{THO}, \mathrm{Th} 1, \mathrm{Th} 2$ and Th1:Th2 cell ratio during normal human pregnancy and preeclampsia. Clin Exp Immunol 1999; 117:550-5.

18. Malek TR. The biology of interleukin-2. Annu Rev Immunol 2008; 26:453-4.

19. Hershko AY, Suzuki R, Charles N, Alvarez-Erico D, Sargent JL, Laurence A. Mast cell interleukin-2 production contributes to suppression of chronic allergic dermatitis. Immunity 2011 ; 35:562-5.

20. Liao W, Lin JX, Leonard WJ. Interleukin-2 at the Crossroads of Effectors Responses, Tolerance, and Immunotherapy. Immunity 2013; 38(1):13-25.

21. Romagnani S. T-cell subsets (Th1 versus Th2). Ann Allergy Asthma Immunol 2000; 85:9-18. 
22. Almedia GD, Porada CD, Joers ST, Ascensao JL. Human cytomegalovirus alters interleukin-6 production by endothelial cells. Blood 1994; 83:370-6.

23. Cruz Spano L, Limma Pereira FE, Gomes da, Silva Basso N, Merco-de-Vargas PR. Human cytomegalovirus infection and abortion: an immunohistochemical study. Med Sci Monit 2002; 8:230-5.

24. Hamai $Y$, Fujii $T$, Yamashita $T$, Nishina $H$, Kozuma S, Mikami $Y$, et al. Evidence for an elevation in serum IL-2 and TNF- $\alpha$ level before the clinical manifestation of preeclampsia. Am J Repord Immunol 1997; 38:89-93.

25. Hamai Y, FuJii T, Yamashita T, Kozuma S, Okai T, Takrtani Y. Pathogenetic implication of IL-2 expressed in preeclamptic decidual tissue: a possible mechanism of deraned vasculature of placenta associated with preeclampsia. Am J Repord Immun1997; 38:83-8.

26. Fang $X$, Yuxiangu HU, Laura AM, Debora MM, David MP, MEL K, et al. An assciation between cytomegalovirus infection and preeclampsia: a case-control study and data synthesis. Acta Obstetricia et Gynecologica 2010; 89:1162-1.

27. ACOG Committee on Obstetric Practice. ACOG practice bulletin. Diagnosis and management of preeclampsia and eclampsia. American College of Obstetricians and Gynecologists. International journal of gynaecology and obstetrics: the official organ of the International Federation of Gynaecology and Obstetrics 2002;100:847-59.

28. Gallersen B, Kemp F, Telgmeen R, DiMattia GE. Non-pituitary human prolactin gene transcription is independent of pit-1 and differentially controlled in lymphocytes and in endometrial stroma. Mol Endocrinol 1994; 8:356-3.

29. Abrahams VM, Visintia I, Aldo PB, Wuller S, Romer R, Mor G. A role for TLRs in the regulation of immune cell migration by first trimester trophoblast cells. J Immunol 2005;175(12):8096104.

30. Kim Ym, Romero R, Oh SV, Kim CJ, Kilburn BA, Armant DR, et al. Toll-like receptor 4: a potential link between danger signals, the innate immune system and pre-eclampsia? Am J Obstet Gynecol 2005; 193:921-7.

31. Mazouni C, Capo C, Leda R. Honstettre A, Agostini A, Capelle M, Mege JL, Bretelle F. Pre-eclampsia: Impaired inflammatory response mediated by Toll-like receptor. J Repod Immunol 2008; 78:80-3.

32. Tanaka K, Yamada H, Minami M, Katoak S, Numazaki K, Minakami H. Screening for vaginal shedding of cytomegalovirus in healthy pregnant women using real-time PCR: Correlation of CMV in the vagina and adverse outcome of pregnancy. J Med Viral 2006; 78(6):757-9.

33. Von Dadelszen P, Megee LA. Could an infections trigger explain the differential maternal response to the shared placental pathology of preeclampsia and normotesive intrauterine growth restriction? Acta Obstet Gynecol Scand 2002; 81:642-8.

34. Xie F, Hu Y, Megee LA, Money DM, Patrick DM, Krajden $M$, et al. An association between cytomegalovirus infection and preeclampsia: a case control study and data synthesis. Acta Obstet Gynecol Scand 2010; 89:1162-7.

35. Von Dadelszen $P$, Magee LA, Krajden M, Alasaly K, Popovska V, Devarakonda RM, et al. Levels of antibodies against CMV an chamydophila pneumoniae are increased in early onset preeclampsia. BJOG 2003; 110:725-33.

36. Trogstand LI, Eskild A, Brau AL, Jeansson S, Jeaum PA. Is preeclampsia an infections disease? Acta Obstet Gynecol Scand 2001; 80:1036-8.

37. Gibson CS, Goldwater PN, MacLennan $\mathrm{AH}$, Haan EA, Priest K, Dekker GA. Fetal exposure to herpes virus may be associated with pregnancy and preterm birth in a Caucasian population. BJOG 2008; 115:492-5.

38. Xie F, Hu Y, Megee LA, Thomas E, Von Dadelszen $P$. Increased Cytomegalovirus antibodies level and DNA loads in early onset of preeclampsia.197 ${ }^{\text {th }}$ ASM General Meeting Toronto, Canada 2007;117:99-8.

39. Strand $\mathrm{KM}$, Odland $\mathrm{ML}$, Iversen $\mathrm{AC}$, Nordbo SA, Vik T, Austgulen R. Cytomegalovirus antibodies status at 17-18 weeks of gestation and preeclampsia: a case-control study of pregnant women in Norway. BJOG 2012; 119:1316-22.

40. Carreiras M, Montagnani S, Layriss Z. Preeclampsia: a multi factorial disease resulting from the interaction of the feto-maternal HLA genotypes and HCMV infection. Am J Reprod Immunol 2002; 48:176-8.

41. Fisher SO, Genbace VE, Maidji I, Pereira L. Human cytomegalovirus infection of placental cytotrophoblast in vitro and in utero: implication for transmission and pathogenesis. J Virology 2000; 74:6808-12.

42. Hamai Y, Fujii T, Yamashita T, Miki A, Hoyodo $\mathrm{H}$, Kozuma $\mathrm{S}$, et al. The expression of human leukocyte antigen-G on trophoblasts abolishes the growth- suppressing effect of interleukin-2 toward them. Am J Reprod Immunol 1999; 41:153-8.

43. Kumazaki K, Ozono K, Yahara T, Wada Y, Suehara N, Takeuchi M, Nakayama M. Detection of cytomegalovirus DNA in human placenta. J Med Virol 2002; 68:363-9.

44. Chou D, Ma Y, Oarry S. Cytomegalovirus shedding in early pregnancy is associated with preterm delivery [abstract]. Housty: J Soc Gynecol Investig 2004; 11:2-3.

45. Yamamoto-Tabata T, McDonagh S, Chang $\mathrm{H}$, Fisher S, Pereira L. Human CMV interleukine-10 down regulates metalloproteinase activity and impairs endothelial cell migration and placental cytotrophoblast invasiveness in vitro. J Virol 2004; 78:2831-4 
The possible role of cytomegalovirus infection .......

Zanco J. Med. Sci., Vol. 22, No. (1), April, 2018

https:/ / doi.org/ 10.15218/ zjms.2018.017

46. Chan G, Hemmings D, Yurochko A, Guilbert L. Human cytomegalovirus-cause damaged to placental trophoblast mediated by immediate-early gene-induced tumor necrosis factor- $\alpha$.. Am J Pathol 2002; 161:1371-8.

47. Grahame-Clarke C. Human cytomegalovirus, Endothelial Function and Atherosclerosis. HERPES 2005; 12(2):42-4. 